\title{
POLSKI SAMORZĄD TERYTORIALNY W EUROPIE. AKTUALNE PROBLEMY I WYZWANIA
}

\section{POLISH TERRITORIAL SELF-GOVERNMENT IN EUROPE: CURRENT PROBLEMS AND CHALLENGES}

\section{Streszczenie}

Artykuł, o tytule odpowiadającym tytułowi tomu, przedstawia ogólne problemy polskiego samorządu terytorialnego, związane z przemianami dokonującymi się w skali polskiej, europejskiej i globalnej. Wychodząc od zasad pomocniczości i decentralizacji, szczególną uwagę poświęcono pozycji samorządu w ramach konstrukcji podziału władz, tradycyjnym i nowym zagrożeniom dla pozycji samorządu, w tym w ramach współczesnych kierunków zarządzania publicznego, specyfice samorządu regionalnego oraz aspektom sieciowości w obecnym i perspektywicznym funkcjonowaniu jednostek samorządu.

Słowa kluczowe: samorząd terytorialny; pomocniczość; podział władz; sieciowość; zarządzanie wielopoziomowe.

\begin{abstract}
The article, the title of which corresponds with the title of the whole volume, sketches general problems of the Polish territorial self-government, connected with changes occurring on a Polish, European, and global scale. Starting with the principles of subsidiarity and decentralization, particular attention is paid to the position of self-government within the theory of separation of powers, to traditional and present
\end{abstract}


threats to the self-government position, also within the framework of contemporary currents of public governance, to specifity of regional self-government, as well as to present and perspective functioning of the self-government entities within the general phenomenon of networking.

Keywords: territorial self-government; subsidiarity; separation of powers; networking; multi-level governance.

Rozważanie aktualnych problemów samorządu terytorialnego zacząć należy od ogólnego stwierdzenia, które ma charakter oczywisty, ale, jak często się zdarza stwierdzeniom oczywistym, nie zawsze jest przedmiotem wystarczającej refleksji - właśnie dlatego, że jest oczywiste. Bez takiej refleksji, wszelka analiza, jeżeli nawet możliwa, nie będzie wystarczająco produktywna.

Mianowicie, samorząd terytorialny stanowi istotny element konstrukcji władz publicznych, a przez to istotnego elementu konstrukcyjnego architektury państwa ${ }^{1}$ - co jest wynikiem potrzeby realizacji zasady pomocniczości i ściśle związanej z nią zasady decentralizacji. O ile jednak pomocniczość stanowi zasadę wykraczającą poza granice poszczególnych państw, odnosi się bowiem także do, w różnych jej wymiarach, włącznie z globalnym, sfery transgranicznej, o tyle zasada decentralizacji wprost określa architekturę państwa.

Obie zasady mają wymiar konstytucyjny - zadeklarowane są, odpowiednio, w preambule Konstytucji RP oraz w art. 15 ust. 1. Stały się one, zwłaszcza zasada decentralizacji, przedmiotem bardzo bogatego orzecznictwa Trybunału Konstytucyjnego, wyjaśniającego różne ich aspekty w kontekście konkretnych rozwiązań ustawowych².

1 Terminu ,architektura państwa” użyłem, w ślad za powołaną literaturą anglosaską, w odniesieniu do podziału terytorialnego, tj. podziału na jednostki samorządu terytorialnego, w opracowaniu Zmiany w zasadniczym podziale terytorialnym państwa. Wybrane aspekty prawne, „Samorząd Terytorialny” 2016, nr 7-8.

2 Por. M. Chmielnicki i K. Lewandowski, Zasada udziału samorzadu terytorialnego w sprawowaniu władzy publicznej na podstawie orzecznictwa Trybunału Konstytucyjnego, ,Studia z Zakresu Prawa, Administracji i Zarzadzania UKW" 2015, t. 3, s. 101 i n.; W. Wytrążek, Decentralizacja administracji publicznej, „Roczniki Nauk Prawnych KUL” 2014, s. 7 i n.; H. Izdebski, Samorzad terytorialny. Podstawy ustroju i funkcjonowania, wyd. 3 [8], Warszawa 2014, s. 26 i n. oraz s. 98 i n. 
Zasada pomocniczości, sformułowana w jej klasycznym kształcie (pomocniczość wertykalna, w odróżnieniu od znacznie bardziej niedawno zaproponowanej pomocniczości horyzontalnej) najpierw w społecznym nauczaniu Kościoła katolickiego (encyklika Quadragesimo Anno Piusa XI z 1931 r.) ${ }^{3}$, stanowi zarazem jedną z podstawowych zasad zarówno konstytucjonalizmu europejskiego (jako zasada prawna praktycznie nie jest znana poza Europa), jak i (w odpowiednio ograniczonej wersji) prawa pierwotnego Unii Europejskiej ${ }^{4}$. Bez zastosowania terminu, zasada pomocniczości znajduje silny wyraz w Europejskiej Karcie Samorządu Lokalnego ${ }^{5}$ - mającej, w świetle art. 91 Konstytucji RP, rangę ponadustawową - oraz, już z zastosowaniem terminu, w Europejskiej Karcie Samorządu Regionalnego - zawierającej standardy „miękkiego prawa” Rady Europy ${ }^{6}$. Europejska Karta Samorządu Lokalnego deklaruje zarazem w preambule kierowanie się zasadą - i wartością - decentralizacji. Dokumenty Rady Europy są o tyle istotne, że wyznaczają standardy, które powinny znajdować zastosowanie nie tylko w państwach członkowskich Unii Europejskiej (z których wszystkie są członkami Rady Europy), ale także w innych państwach członkowskich Rady Europy, w tym w Federacji Rosyjskiej, w Ukrainie i Turcji ${ }^{7}$.

Już tylko tytułem przypomnienia, trzeba wskazać, że zgodnie z art. 16 ust. 2 Konstytucji, do samorządu terytorialnego należy w ramach ustaw (rzecz godna zaznaczenia - w ramach, a nie tylko na podstawie ustaw) istotna część zadań publicznych wykonywanych we własnym imieniu i na własną odpowiedzialność. Sformułowanie to podkreśla miejsce samorządu terytorialnego w systemie władz publicznych - w skali naszego państwa.

Por. H. Izdebski, Historia myśli politycznej i prawnej, wyd. 5, Warszawa 2013, s. 225.

4 Por. H. Izdebski, Doktryny polityczno-prawne. Fundamenty wspótczesnych państw, wyd. 3, Warszawa 2015, s. 170 i n.

5 Dz.U. z 1994 r. Nr 124, poz. 607 ze sprost.

$6 \quad$ O Karcie - H. Izdebski, Rola standardów Rady Europy w dziedzinie organizacji i działania administracji publicznej w Polsce, [w:] H. Machińska (red.), Polska i Rada Europy. 1990-2005, Warszawa 2005, s. 197.

$7 \quad$ Warto mieć także na uwadze fakt, że członkami Rady Europy są postradzieckie państwa niezaliczane do Europy w ujęciu geograficznym: Armenia, Azerbejdżan i Gruzja. 
Przy tak silnym i obszernym umocowaniu samorządu terytorialnego, zastanawiać może pewna słabość doktryny konstytucyjnej, dotycząca właśnie miejsca samorządu terytorialnego w systemie władz publicznych poszczególnych państw - przede wszystkim w systemie władz państwa unitarnego, jakim Rzeczpospolita Polska jest zgodnie z utrwaloną tradycją porozbiorową, potwierdzoną w art. 3 Konstytucji. W państwach opartych na autonomii regionalnej (Włochy, Hiszpania), a także w państwach federalnych, problematyka samorządu regionalnego jest bowiem o tyle szczególna, że ściśle wiąże się $\mathrm{z}$ autonomią bądź federalizmem, a zatem nie można jej traktować jako samoistnej i tym samym odrębnej. Samorząd regionalny państw unitarnych - w swoim zakresie, do czego trzeba będzie jeszcze powrócić, pośredni pomiędzy samorządem lokalnym a państwem sensu stricto, rozumianym jako zespół władz centralnych - jest jednak problemem, z jakim spotykają się państwa większe, podczas gdy samorząd lokalny występuje nawet w najmniejszych demokracjach konstytucyjnych; przykładem może być Księstwo Monaco, w skład którego tylko w latach 1911-1918 wchodziły trzy gminy, a które od tego czasu jest jedną gminą (podzieloną na jednostki pomocnicze), a jego władze komunalne funkcjonują w swoim zakresie działania odrębnie od władz państwowych.

Podstawową zasadą, na której opiera się system władz demokratycznego państwa prawnego - poza, co wynika z mocy szczególnych tradycji ustrojowych, ale i utrwalonego w inny sposób przywiązania do „rządów prawa” i wobec tego konstytucjonalizmu w ścisłym rozumieniu tego pojęcia ${ }^{8}$, Wielką Brytanią i Szwajcarią - jest zasada podziału władz. Francuska Deklaracja Praw Człowieka i Obywatela - która nie stanowi tylko pomnika historii, ale jest uważana za obowiązującą także obecnie - wprost głosi, iż „społeczeństwo, w którym nie ma gwarancji poszanowania praw ani ustanowienia podziału władz, nie ma konstytucji"’.

Tymczasem, wśród dość licznych, wysuwanych od prawie trzech stuleci, koncepcji podziału władz tylko w dwóch można odnaleźć bezpośrednią próbę uwzględnienia samorządu terytorialnego.

Pierwsza - to zaproponowana przez Beniamina Constanta kategoria „władzy municypalnej", funkcjonującej obok neutralnej i moderującej władzy królewskiej, dwóch władz reprezentacyjnych usytuowanych w izbach parlamentu,

8 Por. H. Izdebski. Konstytucjonalizm - legicentryzm - ustawowy nihilizm prawny. O powołaniu naszych czasów do nauki konstytucji, „Państwo i Prawo” 2016, nr 6, s. 5 i n.

$9 \quad$ W. Staśkiewicz (red.), Konstytucje państw Unii Europejskiej, Warszawa 2011, s. 295. 
władzy wykonawczej oraz władzy sądowniczej ${ }^{10}$. O ile konstrukcja „władzy moderującej" znajduje dziś pewne zastosowanie, w szczególności w pozycji głowy państwa w V Republice Francuskiej i próbach jej adaptacji do warunków innych państw (w tym próbie ograniczonej adaptacji w RP) ${ }^{11}$, pozostałe władze Constanta mają charakter raczej archaiczny, dostosowany bardziej do stanu faktycznego i postulowanego w jego czasach (czyli 200 lat temu) niż do warunków i potrzeb naszych czasów. Godne uwagi jest jednak to, że Constant w istocie wyrażał w sposób opisowy istotę ważnego aspektu zasady pomocniczości, gdy głosił: „w każdej gminie każda osoba będzie miała interesy, które jej tylko dotyczą i które przeto nie powinny podlegać jurysdykcji gminy. Inne interesy będą dotyczyły innych mieszkańców gminy, a te należeć będą do kompetencji gminy. Te gminy będą znowu miały interesy wewnętrzne ich samych tyczące się i inne interesy, które się na cały powiat rozciągać będą, Pierwsze zależą prosto od gmin, drugie od powiatu i tak dalej, aż do interesów ogólnych, wspólnych wszystkim jednostkom, miliona składającego się na naród. [...] Według zasad zatem zwierzchność narodowa, zwierzchność powiatowa, zwierzchność gminna mają, każda z osobna, swój własny zakres, w którym powinny zostać; i to nas prowadzi do ustanowienia prawdy, zdaniem naszym fundamentalnej: dotąd uważano władzę miejscową (lokalną) za odnogę zależną od władzy wykonawczej; nie jest jednak tak; nie powinna ona jej przeszkadzać, ale od niej zależeć"12.

O ile ta teoria odrębnej ,władzy municypalnej”, nie znalazłszy, przynajmniej bezpośredniego, odzwierciedlenia w praktyce (na pewno nie w historycznej praktyce francuskiej), ma walor jedynie doktrynalno-historyczny, o tyle druga, do tego starsza od podjętej przez Constanta, próba usytuowania samorządu terytorialnego w konstrukcji podziału władz wykazuje żywotność, lecz tylko na terenie, na którym powstała, czyli w Stanach Zjednoczonych Ameryki (gdzie, trzeba pamiętać, termin self-government ma szczególnie szerokie

10 B. Constant, O monarchii konstytucyjnej i rękojmiach publicznych, red. A. Bosiacki, Warszawa 2016, s. 85 i n. Por. A. Bosiacki, Władza municypalna w ujęciu Benjamina Constanta a teorie podziału władzy, „Studia Iuridica” 2008, t. 48, s. 341 i n.

11 Por. np. M. Bożek, Znaczenie koncepcji władzy neutralnej Benjamina Constanta we współczesnym konstytucjonalizmie, [w:] R.M. Małajny, Konstytucjonalizm a doktryny polityczno-prawne. Najnowsze kierunki badań, Katowice 2008, s. 167 i n.

12 B. Constant, O monarchii konstytucyjnej..., s. 86-87. 
znaczenie, obejmując także instytucje polityczne, jak również samodzielną działalność każdego obywatela) ${ }^{13}$.

Mowa o, przedstawionym przez Thomasa Jeffersona (a także, w węższym zakresie, Jamesa Madisona), rozróżnieniu podziału władz: poziomego (na trzy władze monteskiuszowskie, przy uwzględnieniu szczególnego sposobu ich adaptacji do ustroju USA) i pionowego ${ }^{14}$. Jefferson podkreślał, iż „sposobem na posiadanie dobrego i bezpiecznego rządu jest nie powierzenie jego całości jednej osobie, lecz podzielenie go pomiędzy wielu, poprzez przydzielenie każdemu tych zadań, w które jest on kompetentny"; dotyczyło to nie tylko rozdziału zadań i kompetencji między federacją i stanami, ale także zadań i kompetencji hrabstw i gmin (wards), wszystkich określanych, w nawiązaniu do Arystotelesa i Cycerona, jako republiki ${ }^{15}$. Także i ta wypowiedź może być potraktowana jako opisowe określenie tego, co w Europie nazywa się współcześnie zasadą pomocniczości - tyle że miała ona na celu zrealizowanie podstawowego celu podziału władz, jaką jest zapewnienie wolności jednostce, dzięki czemu wyrażała to, co w Ameryce wciąż określa się jako ,pionowy podział władzy”. Jefferson pisał bowiem: ,poprzez rozdzielenie i podrozdzielenie tych republik, schodząc od wielkiej republiki narodowej poprzez to, co jej podlega (its subordinations), kończy się na tym, że własną farmą zarządza każdy sam. [...] Co zniszczyło wolności i prawa człowieka w każdym rządzie, który kiedykolwiek istniał pod słońcem? Uogólnianie i skupianie wszelkiej pieczy i władzy w jednym ciele. [...] Podstawowe republiki gmin, republiki hrabstw, republiki stanowe i republika Unii, tworzyłyby gradację władz, z których każda opiera się na prawie, posiada swój delegowany udział we władzy i rzeczywiście stanowi system fundamentalnych balances and checks dla rządu".

Konstrukcja pionowego podziału władz jest nie tylko nieprzyjęta, ale wprost kwestionowana w polskiej doktrynie konstytucyjnej. Nie ułatwia to

13 Por. H. Izdebski, Doktryny polityczno-prawne..., s. 263.

14 Por. Z. Lauc, The Vertical Separation of Powers, IX ${ }^{\text {th }}$ World Congress of the IACL, Oslo 2015, https://www.jus.uio.no/english/research/news-and-events/events/conferences/2014/ wccl-cmdc/wccl/papers/ws15/w15-lauc.pdf (dostęp: 01.06.2016 r.) oraz E. Taylor jr., Vertical Separation of Powers - Key to Domestic Tranquility, 2004, http.//www.xmission.com/ nccs/newsletter/nov.04nl.html (dostęp: 23.05.2014 r.).

15 A.E. Bergh (red.), Writings of Thomas Jefferson. Definitive Edition Containing His Autobiography, Notes on Virginia, Parliamentary Manuals, Official Papers, Messages and Addresses, and Other Writings, Official and Private, t. 14, Washington D.C. 1907, s. 421 [List do J.C. Cabella z 2 lutego 1816 r.]. Fragment tej wypowiedzi cytuję w: Doktryny polityczno-prawne..., s. 258. 
określenia miejsca samorządu terytorialnego w systemie władz publicznych, o czym świadczą również wahania Trybunału Konstytucyjnego w tej materii $^{16}$. Najpierw, w orzeczeniu z 23 października 1995 r. uznał on, że samorząd terytorialny, choć nie stanowi odrębnej „władzy samorządowej”, nie może być klasyfikowany wedle reguł trójpodziału władz ${ }^{17}$, co mogło zbliżać do konstrukcji pionowego podziału władz. Następnie jednak Trybunał Konstytucyjny stwierdził, że samorząd terytorialny stanowi segment władzy wykonawczej zajmując zresztą, jeżeli użyje się kategorii silnie obecnych w sporach z okresu II Rzeczypospolitej, stanowisko zbyt etatystyczne, a za mało naturalistyczne, mimo że stanowisko naturalistyczne, oczywiście w postaci umiarkowanej, ma silną konstytucyjną podbudowę w zasadzie pomocniczości. Etatystyczne podejście w jeszcze większym stopniu wydają się reprezentować sądy administracyjne, gdy sprowadzają w istocie do deklaracji politycznej konstytucyjne zasady domniemania zadań i kompetencji samorządu terytorialnego w ogóle, a w obrębie samorządu - zadań i kompetencji gmin ${ }^{18}$.

Nie bez znaczenia może być jednak fakt, że umiarkowane stanowisko naturalistyczne znajduje obecnie doktrynalną podbudowę również w ważnej (i ogólniejszej, bowiem, jak będzie o tym mowa, wykraczającej poza wymiar poszczególnych państw) konstrukcji z zakresu zarządzania publicznego, mianowicie multi-level governance ${ }^{19}$, która w istocie opiera się, choć niekoniecznie explicite, na założeniu istnienia pionowego podziału władz - i to w ujęciu Jeffersonowskim. Podział ten jest jednak nierozerwalnie związany z obowiązkiem współdziałania władz, sformułowanym także w Konstytucji RP (choć nie w art. 10 traktującym o zasadzie podziału władz, lecz w preambule). Bez uwzględnienia tego ostatniego aspektu, potraktowanie samorządu terytorialnego jako (jakiegoś) segmentu władzy wykonawczej nie jest w stanie służyć wyjaśnieniu roli samorządu w architekturze państwa ani w Polsce, ani w Europie - a rola ta zależy także od woli współdziałania samorządów pomiędzy sobą oraz z innymi elementami architektury państwa, jak też podmiotami nienależącymi do tej architektury.

16 Por. H. Izdebski, Doktryny polityczno-prawne..., s. 257 i n. wraz z powołaną tam literaturą.

17 K 4/95, „Orzecznictwo Trybunału Konstytucyjnego” (OTK) 1995, nr 2, poz. 31.

18 Por. H. Izdebski, Doktryny polityczno-prawne..., s. 266.

19 Por. tamże, s. 266 i n. wraz z powołaną literaturą. 
Określona w powyższy sposób pozycja samorządu terytorialnego napotyka współcześnie na różnego rodzaju zagrożenia. Niektóre z nich mają, w pewnym przynajmniej zakresie, charakter tradycyjny. Inne są z kolei charakterystyczne dla naszych czasów.

Za zagrożenia tradycyjne trzeba uznać wszelkiego rodzaju tendencje etatystyczne i centralistyczne. Centralizm połączony z etatyzmem w ogóle stanowi istotny element francuskiej tradycji ustrojowej - i jest we Francji ograniczany dopiero stopniowo, i to nie bez zawirowań; szczególne znaczenie miały reformy sprzed dopiero trzech (z górą) dekad. W wielu państwach występuje - choćby okazywało się ono czasowe - zagrożenie powrotem do centralizmu, w pewnych sytuacjach zmieniające się w taki powrót, w różnych jego gradacjach: od całkowitego w państwach totalitarnych (w tym także w modelu radzieckim) i daleko posuniętego w państwach autorytarnych (czego przykładem może być prawna i faktyczna pozycja samorządu w II Rzeczypospolitej w latach trzydziestych) do mniej czy bardziej częściowego. Od takiej tendencji nie jest też wolna, w szczególności obecnie, III Rzeczpospolita.

Tradycyjny już charakter ma w różnych krajach - także tych tradycyjnie zdecentralizowanych - krytyka samorządu, do której powraca się w różnych kontekstach także współcześnie. Samorząd łączy się zatem z decentralizowaniem korupcji, co ma utrudniać i tak niełatwą walkę $\mathrm{z}$ tym zjawiskiem ${ }^{20}$, jak też twierdzi się, że samorząd ułatwia działania nastawionej na prywatę biurokracji, niepodlegającej wystarczającej kontroli ${ }^{21}$. Za takimi krytykami stoi przeświadczenie - na ogół niepoparte badaniami rzeczywistości, a zatem bardziej polityczno-ideologiczne - że zadania publiczne lepiej wykonuje scentralizowany i odgórnie kontrolowany aparat państwa sensu stricto, a nie samodzielny i pluralistyczny, choć tez mogący alienować się od obywateli, samorząd. Zarazem nie można nie zauważać, że samorząd wymaga stałego dostosowywania do nowych potrzeb i wymagań, a jest on na tyle złożony i inercyjny, że dostosowywanie jest procesem skomplikowanym i trudnym, zwłaszcza, że przeciwstawiają się mu ci, którzy korzystają z wad i braków aktualnego stanu w Polsce można ich zbiorczo określić jako „układy resortowo-korporacyjne"22.

20 Por. P. v. Maravic, Decentralized Corruption in Germany, ,Public Administration Quarterly" t. 30: 2006/7 nr 3-4, s. 440 i n.

21 Por. H. Izdebski, Samorząd..., s. 33-34.

22 J. Bober i in., Narastajace dysfunkcje, zasadnicze dylematy, konieczne działania. Raport o stanie samorządności terytorialnej w Polsce, Kraków 2013, s. 9. 
Za tradycyjne, bo praktykowane już przed II wojną światową, zagrożenie funkcjonowania samorządu terytorialnego należy też uznać decentralizowanie deficytu finansów publicznych - poprzez obciążanie samorządu wieloma nowymi zadaniami publicznymi bez zapewnienia wystarczającego finansowania, a następnie krytykowanie samorządu za niską efektywność jego działania, przy rosnącym zadłużeniu.

Zagrożeniem dla dotychczasowej pozycji samorządu jednocześnie mogą być nowe zjawiska, powiązane ze współczesnymi kierunkami reprezentowanymi w teorii i w praktyce zarządzania publicznego, a występujące już w skali transgranicznej. Mowa, szczególnie, o technokratyczno-menedżerskim „nowym zarządzaniu publicznym", które z istoty swojej nie jest nastawione na sprzyjanie samorządności. Jego istotę stanowi bowiem potraktowanie obywateli jako zatomizowanych klientów usług publicznych, zadanie programowania i organizowania których, w jak najszerszej możliwej skali przedmiotowej i terytorialnej, powinno się powierzyć fachowcom od zarządzania. Oznaczać to musi ograniczenie roli politycznych w swym charakterze samorządów w procesie kształtowania polityk publicznych na rzecz technokratycznego kształtowania ich, do tego na poziomie centralnym ${ }^{23}$.

Reakcja na dominację myślenia - i nierzadko działania - w kategoriach „nowego zarządzania publicznego”, jaką stanowi kierunek określany jako good public governance, w którym obywatel jest traktowany jako interesariusz (stakeholder) mający prawo do uczestniczenia w procesie dotyczących go publicznych rozstrzygnięć indywidualnych i generalnych, zasadniczo powinna służyć zwiększeniu roli samorządów jako bliższych niż władza centralna interesariuszom. Good public governance wymaga jednak, z jednej strony, nowego modelu działania samorządu - praktykowania, zamiast tradycyjnej demokracji pośredniej najwyżej z pewnymi elementami demokracji bezpośredniej w postaci referendum, elastycznej, do tego uprawianej stale, a nie okazjonalnie, demokracji deliberatywnej czy partycypacyjnej ${ }^{24}$. Przejście do tego modelu okazuje się trudne, zwłaszcza w krajach, w których, jak w Polsce, nie

${ }^{23}$ Por. H. Izdebski, Nowe kierunki zarzadzania publicznego a wspólczesne kierunki myśli polityczno-prawnej, [w:] A. Bosiacki, H. Izdebski, A. Nelicki, I. Zachariasz (red.), Nowe zarzadzanie publiczne i public governance w Polsce $i$ w Europie, Warszawa 2010, s. 20 in.

24 Por. np. M. Żardecka-Nowak, Demokracja deliberatywna jako remedium na ponowoczesny kryzys legitymizacji władzy, „Teka Komisji Politologii i Stosunków Międzynarodowych OL PAN" 2008, s. 29 i n. 
ukształtowało się wystarczająco (miejmy nadzieję, jeszcze nie ukształtowało się) społeczeństwo obywatelskie jako, jak zdefiniował je Trybunał Konstytucyjny, ,społeczeństwo wolnych, świadomych, aktywnych i zaangażowanych w sprawy publiczne obywateli"'25.

Demokracja partycypacyjna może, co więcej, kształtować się w pewnym stopniu z pominięciem samorządu, jeżeli okazuje się on niechętny do odchodzenia od tradycji demokracji pośredniej. Wyraża się ona wówczas, poza bardziej wykorzystaniem tradycyjnego kanału organizacji pozarządowych, poprzez aktywność ruchów obywatelskich, w szczególności „ruchów miejskich”, jak również poprzez aktywność i mobilizację obywatelską w internecie. Z drugiej strony, good public governance zakłada multi-level governance, co zasadniczo jest korzystne dla samorządów, ale, nawet jeżeli nastawią się one na praktykowanie demokracji deliberatywnej, oznacza konieczność stałego współdziałania z różnymi szczeblami organizacji społeczeństwa, zarówno ze sfery władz publicznych, także na szczeblu ponadpaństwowym (w szczególności na szczeblu Unii Europejskiej), jak i spoza tej sfery, czyli z organizacjami społeczeństwa obywatelskiego. Przy, panującej wciąż u nas, tradycji samodzielnego i często konkurencyjnego, a nie kooperatywnego, wykonywania zadań i kompetencji przez organy samorządu terytorialnego, współdziałanie może okazać się szczególnie trudne, a to może stanowić kolejne zagrożenie dla odgrywania przez samorząd terytorialny roli, jaka wynika dlań ze standardów konstytucyjnych i europejskich.

Odrębnym zagrożeniem dla samorządu terytorialnego - ale już w ogóle dla państwa w szerokim znaczeniu zespołu władz publicznych, a więc także samorządu - może być, widoczny w wielu krajach, w tym w naszym kraju, kryzys zaufania do instytucji demokracji liberalnej (obecnie, dla uniknięcia dodatkowych sporów ideowych, częściej nazywanej demokracją konstytucyjną), przejawiający się w przejawianiu się nastrojów i tendencji populistycznych. Mimo że demokracja i populizm mają w istocie ten sam źródłosłów - tyle, że w dwóch wielkich językach starożytności: demos i populus - różni je podejście do praw i obowiązków członków wspólnoty państwowej i samorządowej. Demokracja chyba, że jest to demokracja w wypaczonym rozumieniu prostych rządów większości, a ściślej rządów większości tych, którzy wzięli udział w wyborach lub w referendum, a wtedy jest to albo populizm, albo po prostu ukrywanie nihilizmu instytucjonalnego i autorytaryzmu - zawiera w sobie odpowiednio silny element republikanizmu w postaci poczucia współodpowiedzialności każdego za sprawy

25 Wyrok TK z 27 maja 2003 r., K 11/03, OTK-A 2003, nr 5, poz. 43. 
publiczne na każdym szczeblu funkcjonowania instytucji demokratycznych. Populizm skupia się natomiast na utrwalaniu przekonania o odgórnym zapewnieniu realizacji praw (a raczej nie tyle praw, co interesów obywateli) przez władzę, ale $\mathrm{w}$ istocie tylko przez władze państwa w ścisłym znaczeniu, i w tym sensie ma charakter silnie roszczeniowy, a mało wspólnotowy.

Oznaczając odwoływanie się do jednej, scentralizowanej władzy państwowej i kwestionując w istocie całą konstrukcję multi-level governance, obecny w tej chwili w Europie populizm przyczynia się do osłabiania pozycji samorządu terytorialnego w skali szerszej niż tylko jednego państwa - tak jak przyczynia się do pogłębiania zjawisk kryzysowych w Unii Europejskiej, którą, ze względu na jej historycznie złożony charakter, tradycyjnie cechuje do tego deficyt demokracji.

W świetle nie tylko standardów europejskich, ale i art. 164 ust. 2 Konstytucji RP, w obrębie samorządu terytorialnego należy wyróżnić samorząd lokalny i oczywiście w odpowiednio dużych państwach - samorząd regionalny. Szczególną kategorię w ramach samorządu regionalnego (lub subregionalnego) stanowi, w Polsce niestety wciąż niewystępujący, samorząd metropolitalny ${ }^{26}$. Podstawą podziału jest terytorialna skala działania danego samorządu. Mowa o podstawie, którą, odwołując się do terminologii medycznej, można nazwać morfologiczną, ponieważ, w kategoriach fizjologicznych, w istocie idzie nie o różnej wielkości oznaczenia obszarów na mapie, lecz o różne kategorie zadań publicznych, odpowiadające szczeblom pionowego podziału władz realizującego zasadę pomocniczości - w tym o szczególne zadania metropolitalne, co do których nie ma w Polsce podmiotu systemowo odpowiadającego za ich realizację ${ }^{27}$. Kwestia

26 Namiastką samorządu metropolitalnego miały być, zgodnie z ustawą z 9 października 2015 r. o związkach metropolitalnych (Dz.U., poz. 1890), która została uchwalona w wyniku prac parlamentarnych nad poselskim projektem ustawy o powiecie metropolitalnym, związki metropolitalne, tworzone indywidualnymi rozporządzeniami Rady Ministrów. Zapowiedziano już jednak zastąpienie tej, niezastosowanej dotąd, ustawy ustawą dotyczącą jedynie obszaru metropolitalnego Górnego Śląska. Co do zagadnień ogólnych R. Szmytkie, $W$ kwestii metropolii i obszarów metropolitalnych, „Przegląd Administracji Publicznej" 2013, nr 2, s. 35 i n.

27 Por. H. Izdebski, Samorzqd..., s. 155 i n. oraz Zadania metropolitalne i instytucjonalne sposoby ich realizacji, „Samorząd Terytorialny” 2010, nr 6. 
metropolii jest przy tym o tyle fundamentalna, że - mimo prób kwestionowania tego faktu przez wielu polityków (na ogół opacznie rozumiejących zasadę zrównoważonego rozwoju) - to metropolie, tzn. odpowiednio duże i rozwijające się obszary miejskie, są w warunkach globalizacji centrami czy biegunami wzrostu, oddziałującymi, choć nie w sposób automatyczny, na rozwój otaczających regionów i całych państw ${ }^{28}$. Rozwój zaś jest hasłem, pod którym skłonni podpisać się politycy bardzo różnych opcji, choć i różnie go rozumieją, i przedstawiają wizje różnych instrumentów, które mają mu służyć.

Gmina jest, jak stwierdza art. 164 ust. 1 Konstytucji, zasadniczą jednostką samorządu - i jej przypada domniemanie zadań i kompetencji w obrębie samorządu terytorialnego (art. 164 ust. 3 Konstytucji) ${ }^{29}$, a ustawa o samorządzie powiatowym określa powiat jako lokalną wspólnotę samorządową, wykonująca określone ustawami zadania publiczne o charakterze ponadgminnym.

Zadania lokalne są ukierunkowane na zaspokajanie lokalnie czyli ,na miejscu" potrzeb poszczególnych mieszkańców, przy czym zadaniami powiatowymi powinny być takie zadania lokalne, których nie są w stanie efektywnie wykonywać gminy. Odrębną kwestię stanowi to, że kryterium to niekoniecznie znajduje zastosowanie w praktyce, co stanowi jeden z aspektów toczącego się od 1998 r. sporu o przydatność powiatów w architekturze Rzeczypospolitej, który to aspekt można pominąć w niniejszym opracowaniu, mającym ogólniejszy charakter.

Postępujący obecnie proces informatyzacji administracji publicznej może ułatwiać wykonywanie przez samorząd lokalny takich zadań lokalnych, które nie łączą się z koniecznością fizycznego styku obywatela $\mathrm{z}$ odpowiednią agendą administracji reglamentacyjno-porządkowej (jak w sprawie zezwoleń), świadczącej (jak w usługach bibliotek) czy ewidencyjno-rejestracyjnej. Może jednak oznaczać także zagrożenie dla tradycyjnego załatwiania takich spraw „na miejscu”, bowiem umożliwia delokalizację odpowiednich usług, tj. świadczenie ich z dowolnej agendy administracyjnej w kraju, a w perspektywie może

28 Por. W.M. Gaczek, Metropolie jako źródło przewagi konkurencyjnej gospodarki regionu, „Acta Universitatis Lodziensis. Folia Oeconomica” 2010, nr 246, s. 6 i n.; U. Wich, Metropolie - czynnik integracji czy dezintegracji regionów?, „Annales UMCS. Sectio H”, t. 48, 2014, nr 1, s. 193 i n.

29 Por. H. Izdebski, Domniemanie zadań samorzadu terytorialnego i domniemanie zadań gminy w obrębie samorządu terytorialnego - klauzule generalne dotyczace zadań samorządu, „Samorząd Terytorialny” 2015, nr 1-2. 
i spoza kraju, a agenda ta wcale nie musi być samorządowa. Nie wydaje się, by samorządy lokalne były na takie zagrożenie wystarczająco przygotowane.

Z kolei województwo stanowi wspólnotę regionalną, której zadania są ukierunkowane na rozwój (intra)regionalny ${ }^{30}$ i organizację zaspokajania zbiorowych potrzeb mieszkańców w skali pośredniej między „miejscem” a państwem. Aktualne skupienie naszego samorządu województw na dystrybucji środków z funduszy strukturalnych UE (takie zadania i kompetencje samorządu regionalnego są zresztą $w$ ramach całej Unii wyjątkowe) mieści się $w$ ramach ogólnej kategorii działania na rzecz rozwoju regionalnego, lecz może okazać się czasowe. Niezależnie od możliwego rozwoju sytuacji UE w kierunku ograniczenia zakresu jej działania, środki te i tak będą w kolejnej perspektywie finansowej znacznie mniejsze, a to samo w sobie może stać się szczególnym zagrożeniem dla dotychczasowego sposobu funkcjonowania polskiego samorządu regionalnego.

Tym bardziej zatem samorząd regionalny powinien starać się wypracować sobie odpowiednie miejsce pomiędzy - szczególną - polityką lokalną a polityką krajową i, w pewnej mierze, europejską, stając się w ramach multi-level governance i koniecznego współdziałania z wszelkimi partnerami, w coraz większym stopniu także zagranicznymi, ważnym ogniwem kształtowania polityk publicznych odniesionych do warunków regionalnych.

Kilkakrotnie w niniejszym opracowaniu podkreślone zostało znaczenie współdziałania jednostek samorządu pomiędzy sobą oraz w stosunkach z innymi podmiotami - czyli organami administracji rządowej, organizacjami pozarządowymi, ruchami obywatelskimi i w ogóle interesariuszami i ich reprezentacjami.

W obecnych czasach, współdziałanie, przede wszystkim współdziałanie jednostek samorządu pomiędzy sobą, przekracza coraz częściej granice państwowe, a nawet granice Unii Europejskiej, stając się coraz bardziej transgraniczne. Prowadzi to do potrzeby rozważania miejsca samorządu terytorialnego w skali już nie tylko poszczególnych państw, ale i w wymiarze transgranicznym. Zauważać przy tym trzeba nie tylko funkcjonowanie mniej czy bardziej

30 Por. K. Wlaźlak, Rozwój regionalny jako zadanie administracji publicznej, Warszawa 2010. 
ustabilizowanych kontaktów osobistych (do tego wciąż w dużej mierze sprowadza się instytucja partnerskich i bliźniaczych gmin czy miast ${ }^{31}$ ) oraz kontaktów sąsiedzkich jednostek różnych państw ${ }^{32}$, ale kształtowanie się, nie zawsze zinstytucjonalizowanych, sieci kontaktów jednostek samorządu terytorialnego mających zbliżony charakter (np. duże metropolie czy też miasta nadmorskie) i poszukujących rozwiązania konkretnych problemów.

Sieciowość jest jedną z cech współczesnego zarządzania w ogóle, a zarządzania publicznego w szczególności; szeroko używa się takich terminów jak governance network i network governance ${ }^{33}$. Z punktu widzenia sieciowości szczególne znaczenie posiadają metropolie, same z siebie stanowiące węzły różnych sieci: informacyjnych, transportowych, finansowych, naukowych czy kulturalnych. Amerykański politolog Benjamin R. Barber zwraca uwagę na stabilizowanie się w skali globalnej (można dodać, również europejskiej) sieci metropolii - i przypisuje metropoliom wiodącą rolę już nie tylko w zaspokajaniu potrzeb mieszkańców ich rosnących obszarów i otoczenia, ale także w zdemokratyzowaniu globalizacji ${ }^{34}$. Zdaniem tego autora, w zglobalizowanym świecie prawdziwa władza nie znajduje się już w rękach państw, ale należy do miast, a tym samym historia zatacza koło: od państw-miast poprzez państwa narodowe po samorząd wielkich miast. Władze miast, zarządzając skomplikowanym mechanizmem zaspokajania potrzeb lokalnych i metropolitalnych dla wielkiej liczby osób skupionych na relatywnie niewielkim obszarze, muszą cechować się pragmatyzmem i operatywnością, a nie kierować się ideologią i racją stanu, co charakteryzuje władze państw. Władze miast mogą tworzyć sieci operatywnej współpracy, na jakie nie mogą sobie pozwolić rywalizujące ze sobą państwa-dodać można, po

31 Por. Miasta partnerskie. Co nam daje ta wspólpraca?, „Wyborcza.pl Kraków” z 7 października 2013 r., http://krakow-wyborcza.pl/krakow/1,44425,14732542 (dostęp: 30.06 .2016 r.).

32 Mowa, w szczególności, o współpracy sąsiadujących miast granicznych (por. np. J. Jańczak, Integracja i dezintegracja w Europe Środkowej. Graniczne miasta bliźniacze jako laboratoria wspótpracy zagranicznej, „Rocznik Integracji Europejskiej” 2013, nr 7, s. 265 i n.), ale też i o współpracy w ramach euroregionów (por. np. M. Greta, Euroregiony polskie w procesie integracji europejskiej oraz w przezwyciężaniu peryferyjności i dysproporcji regionalnych, Łódź 2013 oraz J.P. Gwizdała, Euroregiony jako forma wspótpracy transgranicznej w Europie, „Zeszyty Naukowe Uniwersytetu Szczecińskiego” nr 855 „Finanse, Rynki Finansowe, Ubezpieczenia” nr 74: 2015, t. 2, s. 449 i n.; ogólnie o współpracy transgranicznej - H. Izdebski, Samorząd.., s. 456 i n.

33 Por. S. Mazur, Wspólzarządzanie a administracja publiczna, [w:] S. Mazur (red.), Wspótzarzadzanie publiczne, Warszawa 2015, s. 41 i n.

34 B.R. Barber, Gdyby burmistrzowie rzadzili światem: dysfunkcyjne kraje, rozkwitajace miasta, Warszawa 2014. 
części także jeżeli stworzyły instytucjonalny mechanizm współpracy, jakim jest Unia Europejska. Barber twierdzi również, że państwo okazuje się zbyt duże, aby zapewnić mieszkańcom realną partycypację, a zarazem zbyt małe, aby, poza wielkimi mocarstwami, mieć wpływ na sprawy globalne. Metropolie pojedynczo są zdolne do zapewnienia partycypacji, a kolektywnie, zdaniem tego autora, mogą mieć wpływ na sprawy globalne.

Choć ostateczny postulat: stworzenie światowego parlamentu burmistrzów największych miast jest - przynajmniej obecnie i w dającym się przewidzieć czasie - całkowicie utopijny, a przedstawione tezy uznać trzeba za ewidentnie nazbyt kategoryczne, w argumentacji Benjamina Barbera można doszukać się dostrzeżenia jednego z niezauważanych na ogół aspektów faktycznych i potencjalnych zmian pozycji określonych samorządów - i to nie tylko w ramach państwa, ale w skali globalnej. Umacnianie roli samorządów dużych miast, także poprzez ich współpracę w skali europejskiej i globalnej, stanowi bowiem jeden ze sposobów reakcji na wyzwania stojące współcześnie już nie tyle przed samorządami, ile przed społeczeństwami. Zapewne, będzie ono prowadzić do stopniowej rekonstrukcji wciąż nazbyt tradycyjnego systemu władz publicznych, który koncentruje się na miejscu samorządu w poszczególnych państwach, podczas gdy samorząd, także lokalny, działać już w niemałym stopniu musi w wymiarze transgranicznym. Aby było to możliwe, musi mieć zapewnione odpowiednie miejsce w architekturze każdego demokratycznego państwa.

\section{Literatura}

1. Barber B.R., Gdyby burmistrzowie rzadzili światem: dysfunkcyjne kraje, rozkwitajace miasta, Warszawa 2014.

2. Bergh A.E., (red.), Writings of Thomas Jefferson. Definitive Edition Containing His Autobiography, Notes on Virginia, Parliamentary Manuals, Official Papers, Messages and Addresses, and Other Writings, Official and Private, t. 14, Washington D.C. 1907.

3. Bober J. i in., Narastajace dysfunkcje, zasadnicze dylematy, konieczne działania. Raport o stanie samorządności terytorialnej w Polsce, Kraków 2013.

4. Bosiacki A., Władza municypalna w ujęciu Benjamina Constanta a teorie podzialu władzy, „Studia Iuridica” 2008, t. 48.

5. Bożek M., Znaczenie koncepcji władzy neutralnej Benjamina Constanta we wspótczesnym konstytucjonalizmie, [w:] R.M. Małajny, Konstytucjonalizm a doktryny polityczno-prawne. Najnowsze kierunki badań, Katowice 2008.

6. Chmielnicki M., Lewandowski K., Zasada udziatu samorzadu terytorialnego w sprawowaniu władzy publicznej na podstawie orzecznictwa Trybunału Konstytucyjnego, ,Studia z Zakresu Prawa, Administracji i Zarzadzania UKW" 2015, t. 3. 
7. Constant B., O monarchii konstytucyjnej i rękojmiach publicznych, red. A. Bosiacki, Warszawa 2016.

8. Greta M., Euroregiony polskie w procesie integracji europejskiej oraz $w$ przezwyciężaniu peryferyjności i dysproporcji regionalnych, Łódź 2013.

9. Gwizdała J.P., Euroregiony jako forma wspótpracy transgranicznej w Europie, ,Zeszyty Naukowe Uniwersytetu Szczecińskiego” nr 855 - „Finanse, Rynki Finansowe, Ubezpieczenia" nr 74: 2015, t. 2.

10. Izdebski H., Konstytucjonalizm - legicentryzm - ustawowy nihilizm prawny. O powolaniu naszych czasów do nauki konstytucji, „Państwo i Prawo” 2016, nr 6.

11. Izdebski H., Nowe kierunki zarzadzania publicznego a współczesne kierunki myśli polityczno-prawnej, [w:] A. Bosiacki, H. Izdebski, A. Nelicki, I. Zachariasz (red.), Nowe zarzadzanie publiczne i public governance w Polsce $i$ w Europie, Warszawa 2010.

12. Izdebski H., Rola standardów Rady Europy $w$ dziedzinie organizacji $i$ dziatania administracji publicznej w Polsce, [w:] H. Machińska (red.), Polska i Rada Europy. 1990-2005, Warszawa 2005.

13. Izdebski H., Samorzad terytorialny. Podstawy ustroju i funkcjonowania, wyd. 3 [8], Warszawa 2014.

14. Izdebski H., Zmiany w zasadniczym podziale terytorialnym państwa. Wybrane aspekty prawne, „Samorząd Terytorialny” 2016, nr 7-8.

15. Jańczak J., Integracja i dezintegracja w Europe Środkowej. Graniczne miasta bliźniacze jako laboratoria współpracy zagranicznej, „Rocznik Integracji Europejskiej” 2013, nr 7.

16. Lauc Z., The Vertical Separation of Powers, IX ${ }^{\text {th }}$ World Congress of the IACL, Oslo 2015, https:/www.jus.uio.no/english/research/news-and-events/events/conferences/2014/wccl-cmdc/wccl/papers/ws15/w15-lauc.pdf (dostęp: 01.06.2016 r.).

17. Maravic P. v., Decentralized Corruption in Germany, „Public Administration Quarterly” t. 30: 2006/7, nr 3-4.

18. Mazur S., Wspótzarządzanie a administracja publiczna, [w:] S. Mazur (red.), Wspótzarzadzanie publiczne, Warszawa 2015.

19. Miasta partnerskie. Co nam daje ta współpraca?, „Wyborcza.pl Kraków” z 7 października 2013 r., http://krakow-wyborcza.pl/krakow/1,44425,14732542 (dostęp: 30.06 .2016 r.).

20. Staśkiewicz W. (red.), Konstytucje państw Unii Europejskiej, Warszawa 2011.

21. Szmytkie R., W kwestii metropolii i obszarów metropolitalnych, ,Przegląd Administracji Publicznej" 2013, nr 2.

22. Taylor E. jr., Vertical Separation of Powers - Key to Domestic Tranquility, 2004, http:// www.xmission.com/nccs/newsletter/nov.04nl.html (dostęp: 23.05.2014 r.).

23. Wytrążek W., Decentralizacja administracji publicznej, „Roczniki Nauk Prawnych KUL” 2014.

24. Żardecka-Nowak M., Demokracja deliberatywna jako remedium na ponowoczesny kryzys legitymizacji władzy, ,Teka Komisji Politologii i Stosunków Międzynarodowych OL PAN" 2008.

Hubert Izdebski

SWPS Uniwersytet Humanistycznopołeczny 